Article

\title{
Effects of Chopping Length and Additive on the Fermentation Quality and Aerobic Stability in Silage of Leymus chinensis
}

\author{
Zhiqiang Sun ${ }^{1}{ }^{\oplus}$, Tingting Jia ${ }^{1}$, Run Gao ${ }^{1}$, Shengyang $\mathrm{Xu}^{1}{ }^{1}$, Zhe $\mathrm{Wu}^{1}{ }^{1}$, Bing Wang $^{2} \mathbb{D}$ and \\ Zhu Yu ${ }^{1, *}$ \\ 1 College of Grassland Science and Technology, China Agricultural University, Beijing 100193, China; \\ BS20193040405@cau.edu.cn (Z.S.); B20163040303@cau.edu.cn (T.J.); gaorun@cau.edu.cn (R.G.); \\ sy20193040640@cau.edu.cn (S.X.); wuzhe@cau.edu.cn (Z.W.) \\ 2 State Key Laboratory of Animal Nutrition, College of Animal Science and Technology, China Agricultural \\ University, Beijing 100193, China; wangb@cau.edu.cn \\ * Correspondence: 02059@cau.edu.cn; Tel.: +86-010-6273-3414
}

Received: 12 September 2020; Accepted: 12 October 2020; Published: 14 October 2020

check for updates

\begin{abstract}
The objective of this experiment was to evaluate the effects of the chopping length and additive on the fermentation characteristics and aerobic stability in silage of Leymus chinensis. L. chinensis was chopped to $1-2 \mathrm{~cm}$ and $4-5 \mathrm{~cm}$, and immediately ensiled with the three treatments, i.e., $2 \%$ sucrose (fresh weight basis; SU), $1 \times 10^{5} \mathrm{cfu} / \mathrm{g}$ Lactobacillus plantarum (LP) or $1 \times 10^{5} \mathrm{cfu} / \mathrm{g}$ LP plus $2 \%$ sucrose $(\mathrm{SU}+\mathrm{LP})$. Silage treated with distilled water served as the control. After silage processing for 30 and $90 \mathrm{~d}$, the fermentation quality of L. chinensis silage was evaluated. The composition of the fermentation products and the $\mathrm{pH}$ value in the silage were determined at 1, 3, 5 and $7 \mathrm{~d}$ after opening the silo. The results showed that in L. chinensis silage there was a lower $\mathrm{pH}$ value, higher lactic acid content and better aerobic stability at the $1-2 \mathrm{~cm}$ length than those at the $4-5 \mathrm{~cm}(p<0.001)$. When the chopping length was $4-5 \mathrm{~cm}$, the addition of either LP or SU+LP increased the content of lactic acid and acetic acid, and decreased the $\mathrm{pH}$ value and butyric acid content, compared to those of the control and SU treatment $(p<0.001)$. Furthermore, combination treatment of SU+LP performed better than LP alone, and the aerobic stability time of L. chinensis silage at 4-5 cm without any additives was the worst. In conclusion, enhanced fermentation quality and aerobic stability can be obtained by processing L. chinensis silage with the shorter length. When the L. chinensis is cut longer, e.g., 4-5 cm in this study, LP or SU+LP could be used as an effective method to improve the fermentation quality and aerobic stability of L. chinensis silage.
\end{abstract}

Keywords: silage processing; fermentation quality; Leymus chinensis; aerobic stability; Lactobacillus plantarum

\section{Introduction}

Leymus chinensis (Trin.) Tzvel., which is commonly known as Chinese wildrye, is a native cool-season perennial grass in the Gramineae tribe and a good forage source for ruminants [1]. Nowadays, it is widely distributed on the Eurasian Steppe, including the eastern Inner Mongolian Plateau and the Songnen Plain in China [2,3]. Fresh tender stems and leaves have good palatability, and higher levels of digestible fiber in L. chinensis [4]. Generally, L. chinensis is usually processed for hay and silage [5]. The hay preparation includes processing and storage, and during these processes the loss of nutrients can reach $28 \%-32 \%$ [6]. Moreover, hay preparation is easily affected by external factors such as the mowing period, weather and others, and especially rain causes mildew growth and deterioration in forage grass [7,8]. Therefore, processing L. chinensis for silage is an effective way 
to utilize natural grassland. The processing of silage under sealed anaerobic conditions can reduce the loss of nutrients, which in turn provides high-quality fermented green forage for livestock in winter [9]. However, L. chinensis silage is not easily processed for ensiling because of its relatively low concentration of lactic acid bacteria (LAB) and water-soluble carbohydrate (WSC) content during ensiling $[1,10]$. Moreover, the hollow and hard stems impede the creation of anaerobic conditions for successful ensiling [11]. In addition, the raw material characteristics of L. chinensis and mechanical limitations prevent the cutting of L. chinensis into short segments, which increases the quantity of oxygen entrapped in the silage and may result in poor silage preservation [12]. L. chinensis silage also deteriorates easily when exposed to air [1]. Thus, more efforts are needed to improve the fermentation and aerobic stability of $L$. chinensis silage.

In our previous studies, organic acids, chemical additives and LAB strains were used to improve the fermentation quality and aerobic stability of forage silage $[1,10]$. It is well documented that homofermentative bacterial inoculants ferment WSC into organic acids, particularly lactic acid (LA), which improve the fermentation of silage [13]. Sucrose is usually used as an additive to improve the fermentation quality of grass silage or to reduce the aerobic deterioration of silage, especially for plants with lower WSC contents [14,15]. Applying a combination of these two types of additives may be more effective than using one type of additive alone [16]. In addition, the cutting length also influences the density of compaction and the followed fermentation characteristics [12,17]. However, to our knowledge, only a few studies have investigated the effects of proper lengths and additives on improving the fermentation quality and suppressing aerobic deterioration of L. chinensis silage.

The aim of our study was to detect the effects of chopping length and additives on the fermentation quality of L. chinensis silage. Furthermore, the levels of in acidic substances associated with the aerobic stability during the aerobic exposure were also measured.

\section{Materials and Methods}

\subsection{Forage Harvest and Silage Preparation}

The heading stage of L. chinensis was harvested in July 2018 at Guyuan, Hebei Province, China $\left(41^{\circ} 42^{\prime}-41^{\circ} 57^{\prime} \mathrm{N}, 115^{\circ} 32^{\prime}-115^{\circ} 59^{\prime} \mathrm{E}\right.$, altitude $\left.1430 \mathrm{~m}\right)$. The materials of L. chinensis were collected and chopped to $1-2 \mathrm{~cm}$ or $4-5 \mathrm{~cm}$, and immediately ensiled with the three treatments, i.e., sucrose at $2 \%$ of the silage fresh weight (SU), $1 \times 10^{5} \mathrm{cfu} / \mathrm{g}$ Lactobacillus plantarum KR107060 (LP), which was isolated from L. chinensis by Zhang et al. [10] or $1 \times 10^{5} \mathrm{cfu} / \mathrm{g}$ LP plus sucrose at $2 \%$ of the silage fresh weight $(\mathrm{SU}+\mathrm{LP})$. At the same time, silages treated with distilled water served as the control. The L. chinensis from each pile was packed in $1 \mathrm{~L}$ bucket silos and sealed with plastic lids. The targeted packing density was $600 \mathrm{~kg} / \mathrm{m}^{3}$. Laboratory silos were stored at room temperature for ensiling $30 \mathrm{~d}$ and $90 \mathrm{~d}$. The three replicates were included in each treatment, with 48 silos in all.

\subsection{Fermentation Quality and Microbial Counts}

Upon silo opening, $20 \mathrm{~g}$ of the silage from each bucket was diluted with $180 \mathrm{~mL}$ of sterilized distilled water, homogenized for $1 \mathrm{~min}$ via 30 pulses of $2 \mathrm{~s}$ using a plant tissue crusher (WaringTM-8010S; Waring Laboratory Science, Kendall, TX, USA) and then filtered through four layers of cheesecloth and a qualitative filter paper. The $\mathrm{pH}$ of the filtrate was measured with a glass-electrode $\mathrm{pH}$ meter (PHS-3C; Shanghai Precision \& Scientific Instrument Co. Ltd., Shanghai, China). The filtrate was further processed with a dialyzer of $0.22 \mu \mathrm{m}$ and then kept at $-20{ }^{\circ} \mathrm{C}$ for organic acid analysis. The LA, acetic acid (AA), propionic acid (PA) and butyric acid (BA) contents were determined by high-performance liquid chromatography (HPLC; Shimadzu, Tokyo, Japan) [18]. The HPLC conditions were as follows: column, Shodex RSpak KC-811S-DVB gel C $(8.0 \mathrm{~mm} \times 30 \mathrm{~cm}$; Shimadzu, Tokyo, Japan); oven temperature, $50{ }^{\circ} \mathrm{C}$; mobile phase, $3 \mathrm{mmol} / \mathrm{L} \mathrm{HClO}_{4}$; flowrate, $1.0 \mathrm{~mL} / \mathrm{min}$; injection volume, $5 \mu \mathrm{L}$; and detector, SPD-M10AVP. For the microbial counts, $10 \mathrm{~g}$ of the sample was ten-fold serially diluted with sterilized saline solution $(0.85 \% \mathrm{NaCl})$. The numbers of mold and yeast were 
counted according to Zhang et al. [10,19]. And the microbial counts were transformed to $\log _{10}$ and presented on a fresh matter (FM) basis.

\subsection{Chemical Composition Analyzes}

The pre-ensiled materials of $L$. chinensis were collected for chemical analysis. The dry matter (DM) content was determined after oven-drying the samples for $48 \mathrm{~h}$ at $65{ }^{\circ} \mathrm{C}$. The dried samples were ground to $1 \mathrm{~mm}$ screen using a microplant grinding machine. Using an automatic fiber analyzer (Ankom 2000i full; Ankom Tech Co., Macedon, NY, USA), the neutral detergent fiber (NDF) and acid detergent fiber (ADF) were determined according to the methods by Van Soest [20]. The crude protein (CP) content was analyzed by using method of the Association of Official Analytical Chemists [21]. The content of WSC were determined by the anthrone-sulfuric acid method [22].

\subsection{Aerobic Stability}

After ensiling for $90 \mathrm{~d}$, the plastic buckets were opened, and $300 \mathrm{~g}$ of L. chinensis silages were placed loosely back into 1-L plastic buckets. The aerobic stability was defined as the number of hours before the silage temperatures increased to $2{ }^{\circ} \mathrm{C}$ above the ambient temperature [23]. The ambient temperature and silage temperature were measured at 5-min intervals using a temperature recorder (SMOWO MDL-1048A, Shanghai Tianhe Automation Instrument Co., Ltd., Shanghai, China). Three buckets were used for temperature recording over $7 \mathrm{~d}$ of exposure to air. Other silage samples were collected from another three buckets, and the $\mathrm{pH}$ value and composition of the fermentation products of the L. chinensis silages were determined at 1,3,5 and $7 \mathrm{~d}$ after silo opening.

\subsection{Statistical Analysis}

The data were collated in Excel 2010. Duncan's multiple comparison method was used to analyze the two factors of different additives and lengths. Significance was declared at $p<0.05$. All of the above statistical analyzes were performed with the GLM procedure in SPSS 19.0. The data are presented as the means and standard error of the mean (SEM).

\section{Results}

\subsection{Chemical Composition of Fresh Forage}

As shown in Table 1, the DM content of L. chinensis before ensiling was $450.06 \mathrm{~g} / \mathrm{kg}$, the WSC content was $62.86 \mathrm{~g} / \mathrm{kg} \mathrm{DM}$, and the CP content was $67.08 \mathrm{~g} / \mathrm{kg} \mathrm{DM}$. The NDF and ADF contents were $619.75 \mathrm{~g} / \mathrm{kg}$ DM and $329.62 \mathrm{~g} / \mathrm{kg} \mathrm{DM}$, respectively.

Table 1. Chemical composition of L. chinensis material before ensiling ( $\pm \mathrm{SD})$.

\begin{tabular}{cc}
\hline Item & L. chinensis \\
\hline Dry matter $(\mathrm{g} / \mathrm{kg})$ & $450.06 \pm 0.77$ \\
Crude protein $(\mathrm{g} / \mathrm{kg} \mathrm{DM})$ & $67.08 \pm 0.34$ \\
Water soluble carbohydrates $(\mathrm{g} / \mathrm{kg} \mathrm{DM})$ & $62.86 \pm 1.59$ \\
Neutral detergent fiber $(\mathrm{g} / \mathrm{kg} \mathrm{DM})$ & $619.75 \pm 12.01$ \\
Acid detergent fiber $(\mathrm{g} / \mathrm{kg} \mathrm{DM})$ & $329.62 \pm 5.81$ \\
\hline
\end{tabular}

\subsection{Fermentation Traits of L. chinensis Silage for Ensiling $30 \mathrm{~d}$}

The fermentation quality of $L$. chinensis silage with different chopping lengths and additives ensiled for $30 \mathrm{~d}$ is shown in Table 2. The chopping length and additives both affected the $\mathrm{pH}$ value of the silage, and shorter silage lengths resulting in lower $\mathrm{pH}$ values $(p<0.001)$. At a length of $1-2 \mathrm{~cm}$, the $\mathrm{pH}$ value of $L$. chinensis silage treated with all additives was lower than that of the control $(p<0.001)$. At a length of 5-6 cm, pH value did not differ between the control and SU but decreased under the LP and SU+LP 
treatment $(p<0.001)$. The $\mathrm{pH}$ values in the SU+LP silages were the lowest at all lengths $(p<0.001)$. The silage of shorter-length $L$. chinensis had a higher LA content compared to the longer-length silage for the SU, LP and control treatments $(p<0.001)$. The LA content of the LP treatment was higher than that of the control for all lengths tested $(p<0.001)$. In contrast, the shorter-length $L$. chinensis silage had a lower AA content compared to the longer-length silage $(p<0.001)$. At the $1-2 \mathrm{~cm}$ length, SU+LP increased the AA content of L. chinensis silage $(p<0.001)$. At both $1-2 \mathrm{~cm}$ and $5-6 \mathrm{~cm}$ lengths, there was no significant difference $(p>0.05)$ in the PA and BA contents in SU and SU+LP, compared to the control. At the 1-2 cm length, LP significantly decreased the PA content $(p<0.05)$. At the $5-6 \mathrm{~cm}$ length, significant differences were not observed in the PA content $(p>0.05)$. BA was detected in all treatments, but the contents were close to zero.

Table 2. The $\mathrm{pH}$ value and fermentation products of $L$. chinensis silage with different chopping lengths and additives after ensiling for $30 \mathrm{~d}$ (Dry matter basis).

\begin{tabular}{|c|c|c|c|c|c|c|c|c|c|}
\hline \multirow{2}{*}{ Item } & \multirow{2}{*}{ Length } & \multicolumn{4}{|c|}{ Additive } & \multirow{2}{*}{ SEM } & \multicolumn{3}{|c|}{$p$-Value } \\
\hline & & Control & SU & $\mathbf{L P}$ & SU+LP & & Length & Additive & Interaction \\
\hline \multirow{2}{*}{$\mathrm{pH}$} & $1-2 \mathrm{~cm}$ & $4.20^{\mathrm{aB}}$ & $4.00^{\mathrm{bB}}$ & $4.06^{\mathrm{bB}}$ & $3.88^{\mathrm{cB}}$ & \multirow{2}{*}{0.014} & \multirow{2}{*}{$<0.001$} & \multirow{2}{*}{$<0.001$} & \multirow{2}{*}{$<0.001$} \\
\hline & $4-5 \mathrm{~cm}$ & $4.64^{\mathrm{aA}}$ & $4.58^{\mathrm{aA}}$ & $4.14^{\mathrm{bA}}$ & $3.99 \mathrm{bA}$ & & & & \\
\hline \multirow{2}{*}{$\begin{array}{l}\text { Lactic acid } \\
\quad(\mathrm{g} / \mathrm{kg})\end{array}$} & $1-2 \mathrm{~cm}$ & $32.53 \mathrm{bA}$ & $40.20^{\mathrm{bA}}$ & $51.77^{\mathrm{aA}}$ & $38.50^{\mathrm{b}}$ & \multirow{2}{*}{0.801} & \multirow{2}{*}{$<0.001$} & \multirow{2}{*}{$<0.001$} & \multirow{2}{*}{$<0.001$} \\
\hline & $4-5 \mathrm{~cm}$ & $4.60^{\mathrm{bB}}$ & $3.77^{b B}$ & $34.36^{\mathrm{aB}}$ & $37.03^{\mathrm{a}}$ & & & & \\
\hline \multirow{2}{*}{$\begin{array}{l}\text { Acetic acid } \\
(\mathrm{g} / \mathrm{kg})\end{array}$} & $1-2 \mathrm{~cm}$ & $6.37^{\mathrm{bB}}$ & $3.53^{\mathrm{bB}}$ & $5.97^{\mathrm{bB}}$ & $13.50^{\mathrm{a}}$ & \multirow{2}{*}{0.433} & \multirow{2}{*}{$<0.001$} & \multirow{2}{*}{0.007} & \multirow{2}{*}{0.002} \\
\hline & $4-5 \mathrm{~cm}$ & $18.70^{\mathrm{A}}$ & $19.83^{\mathrm{A}}$ & $21.90^{\mathrm{A}}$ & 19.33 & & & & \\
\hline \multirow{2}{*}{$\begin{array}{l}\text { Propionic } \\
\text { acid }(\mathrm{g} / \mathrm{kg})\end{array}$} & $1-2 \mathrm{~cm}$ & $10.47^{\mathrm{a}}$ & $8.87^{b}$ & $7.90^{\mathrm{bB}}$ & $9.33^{a b}$ & \multirow{2}{*}{0.186} & \multirow{2}{*}{0.017} & \multirow{2}{*}{0.589} & \multirow{2}{*}{0.008} \\
\hline & $4-5 \mathrm{~cm}$ & 9.57 & 9.70 & $11.27^{\mathrm{A}}$ & 9.97 & & & & \\
\hline \multirow{2}{*}{$\begin{array}{l}\text { Butyric acid } \\
\qquad(\mathrm{g} / \mathrm{kg})\end{array}$} & $1-2 \mathrm{~cm}$ & 1.23 & 1.53 & 1.76 & 1.56 & \multirow{2}{*}{0.212} & \multirow{2}{*}{0.672} & \multirow{2}{*}{0.235} & \multirow{2}{*}{0.678} \\
\hline & $4-5 \mathrm{~cm}$ & $0.70^{\mathrm{b}}$ & $1.00^{a b}$ & $2.63^{a}$ & $1.03^{a b}$ & & & & \\
\hline
\end{tabular}

Means with in the same row ${ }^{(\mathrm{a}-\mathrm{c})}$ or with in the same column ${ }^{(\mathrm{A}, \mathrm{B})}$ with different superscripts differ significantly $(p<0.05)$; SU, sucrose; LP, Lactobacillus plantarum; SEM, standard error of the mean.

\subsection{Fermentation Traits of L. chinensis Silage for Ensiling $90 \mathrm{~d}$}

The fermentation quality of L. chinensis silage ensiled for $90 \mathrm{~d}$ is shown in Table 3 . The addition of $\mathrm{LP}$ or SU+LP significantly decreased the $\mathrm{pH}$ value, and the $\mathrm{pH}$ values of the SU+LP silages were the lowest for all lengths tested $(p<0.001)$. Furthermore, similar to the case for silage ensiled for $30 \mathrm{~d}$, the silage $\mathrm{pH}$ value of the $1-2 \mathrm{~cm}$-length was significantly lower than that of the $4-5 \mathrm{~cm}$-length silage for all the additives $(p<0.001)$. When the chopping length was $1-2 \mathrm{~cm}$, there was no significant effect on the LA content in all treatments $(p>0.05)$. However, at the $4-5 \mathrm{~cm}$ length, with the addition of LP and SU+LP, the LA content increased from $12.30 \mathrm{~g} / \mathrm{kg}$ DM to $30.27 \mathrm{~g} / \mathrm{kg}$ DM and $26.25 \mathrm{~g} / \mathrm{kg}$ DM, respectively. Moreover, the silage of both $\mathrm{LP}$ and SU+LP had a higher level of AA for all chopping lengths. Treatment with SU+LP resulted in lower PA contents for all lengths $(p<0.001)$. With no additives, differences were not observed in the PA contents for all chopping lengths tested $(p>0.05)$. Compared with silage ensiled for $30 \mathrm{~d}$, higher BA was detected with the addition of SU at all chopping lengths and with no additives at the $4-5 \mathrm{~cm}$ length. The yeast counts in L. chinensis silage treated with LP were $1 \times 10^{2.71}$ and $1 \times 10^{2.56} \mathrm{cfu} / \mathrm{g}$ FM at the $1-2 \mathrm{~cm}$ length and the $4-5 \mathrm{~cm}$ length, respectively. At the 1-2 cm length, lower yeast and mold counts were observed of L. chinensis silage compared to the 4-5 cm length. At the $4-5 \mathrm{~cm}$ length, SU+LP decreased the yeast and mold counts of L. chinensis silage compared to the control. 
Table 3. The $\mathrm{pH}$ value and fermentation products of $L$. chinensis silage with different chopping lengths and additives after ensiling for $90 \mathrm{~d}$ (Dry matter basis).

\begin{tabular}{|c|c|c|c|c|c|c|c|c|c|}
\hline \multirow{2}{*}{ Item } & \multirow{2}{*}{ Length } & \multicolumn{4}{|c|}{ Additive } & \multirow[t]{2}{*}{ SEM } & \multicolumn{3}{|c|}{$p$-Value } \\
\hline & & Control & SU & LP & SU+LP & & Length & Additive & Interaction \\
\hline \multirow{2}{*}{$\mathrm{pH}$} & $1-2 \mathrm{~cm}$ & $4.11^{\mathrm{aB}}$ & $4.07 \mathrm{aB}$ & $4.00^{b}$ & $3.85^{c}$ & \multirow{2}{*}{0.028} & \multirow{2}{*}{$<0.001$} & \multirow{2}{*}{$<0.001$} & \multirow{2}{*}{$<0.001$} \\
\hline & $4-5 \mathrm{~cm}$ & $4.94^{\mathrm{aA}}$ & $4.61^{\mathrm{aA}}$ & $4.01^{b}$ & $3.91^{b}$ & & & & \\
\hline \multirow{2}{*}{$\begin{array}{l}\text { Lactic acid } \\
\quad(\mathrm{g} / \mathrm{kg})\end{array}$} & $1-2 \mathrm{~cm}$ & $34.72 \mathrm{~A}$ & $27.42^{\mathrm{A}}$ & $38.69^{\mathrm{A}}$ & 35.44 & \multirow{2}{*}{1.046} & \multirow{2}{*}{$<0.001$} & \multirow{2}{*}{$<0.001$} & \multirow{2}{*}{0.054} \\
\hline & $4-5 \mathrm{~cm}$ & $12.30^{\mathrm{bB}}$ & $7.32^{\mathrm{bB}}$ & $30.27^{\mathrm{aB}}$ & $26.25^{a}$ & & & & \\
\hline \multirow{2}{*}{$\begin{array}{l}\text { Acetic acid } \\
\quad(\mathrm{g} / \mathrm{kg})\end{array}$} & $1-2 \mathrm{~cm}$ & $8.03^{b}$ & $16.79 \mathrm{aA}$ & $21.44^{\mathrm{a}}$ & 8.09 bB & \multirow{2}{*}{0.557} & \multirow{2}{*}{0.899} & \multirow{2}{*}{$<0.001$} & \multirow{2}{*}{$<0.001$} \\
\hline & $4-5 \mathrm{~cm}$ & $9.67^{c}$ & $4.01 \mathrm{~dB}$ & $22.65^{a}$ & $18.62^{\mathrm{bA}}$ & & & & \\
\hline \multirow{2}{*}{$\begin{array}{l}\text { Propionic } \\
\text { acid }(\mathrm{g} / \mathrm{kg})\end{array}$} & $1-2 \mathrm{~cm}$ & $10.67^{\mathrm{a}}$ & $8.19^{b}$ & $11.10^{\mathrm{aA}}$ & $6.22^{c}$ & \multirow{2}{*}{0.194} & \multirow{2}{*}{0.262} & \multirow{2}{*}{$<0.001$} & \multirow{2}{*}{0.156} \\
\hline & $4-5 \mathrm{~cm}$ & $9.70^{\mathrm{a}}$ & $8.22^{a b}$ & $9.45^{\mathrm{aB}}$ & $7.00^{b}$ & & & & \\
\hline \multirow{2}{*}{$\begin{array}{l}\text { Butyric acid } \\
\quad(\mathrm{g} / \mathrm{kg})\end{array}$} & $1-2 \mathrm{~cm}$ & ND & $16.87^{\mathrm{aB}}$ & $0.38^{b}$ & ND & \multirow{2}{*}{3.450} & \multirow{2}{*}{0.072} & \multirow{2}{*}{0.106} & \multirow{2}{*}{0.299} \\
\hline & $4-5 \mathrm{~cm}$ & 33.26 & $34.69^{\mathrm{A}}$ & ND & ND & & & & \\
\hline \multirow{2}{*}{$\begin{array}{l}\text { Yeast (Log } \log _{10} \\
\text { cfu/g FM) }\end{array}$} & $1-2 \mathrm{~cm}$ & $<2$ & $<2$ & 2.71 & $<2$ & & & & \\
\hline & $4-5 \mathrm{~cm}$ & 3.63 & $<2$ & 2.56 & $<2$ & & & & \\
\hline \multirow{2}{*}{$\begin{array}{l}\text { Mold (Log } 10 \\
\text { cfu/g FM) }\end{array}$} & $1-2 \mathrm{~cm}$ & $<2$ & $<2$ & $<2$ & $<2$ & & & & \\
\hline & $4-5 \mathrm{~cm}$ & 2.45 & $<2$ & 2.03 & $<2$ & & & & \\
\hline
\end{tabular}

\subsection{Aerobic Stability of L. chinensis Silage}

The temperature changes of $L$. chinensis silage were examined with the time of aerobic exposure at lengths of $1-2 \mathrm{~cm}$ (Figure 1) and 4-5 cm (Figure 2). We found that the temperature of L. chinensis silage increased firstly and then decreased with the increased of aerobic exposure time. At the 1-2 cm length, after $120 \mathrm{~h}$ of aerobic exposure, the temperature of silage treated with sucrose was $2{ }^{\circ} \mathrm{C}$ higher than the ambient temperature. Silage treated with SU+LP and the control almost exceeded the ambient temperature by $2{ }^{\circ} \mathrm{C}$ at the same time. Under this test condition, the temperature of $L$. chinensis silage treated with LP was always lower than the ambient temperature by $2{ }^{\circ} \mathrm{C}$ after aerobic exposure. At the $4-5 \mathrm{~cm}$ length, after $50 \mathrm{~h}$ of aerobic exposure, the temperature of $L$. chinensis silage with no additive exceeded the ambient temperature by $2{ }^{\circ} \mathrm{C}$, and after $70 \mathrm{~h}$ of aerobic exposure, the highest temperature was observed. The aerobic stability of L. chinensis silage can be improved with the addition of LP, SU or SU+LP. When exposed to air, the temperature of L. chinensis treated with SU and LP exceeded the ambient temperature by $2{ }^{\circ} \mathrm{C}$ after $120 \mathrm{~h}$ and $160 \mathrm{~h}$, respectively. A factorial analysis revealed that the length, additive and their interactions had significant effects $(p<0.001)$ on the aerobic stability and the time required to reach the maximum temperature of L. chinensis silage (Table 4). 


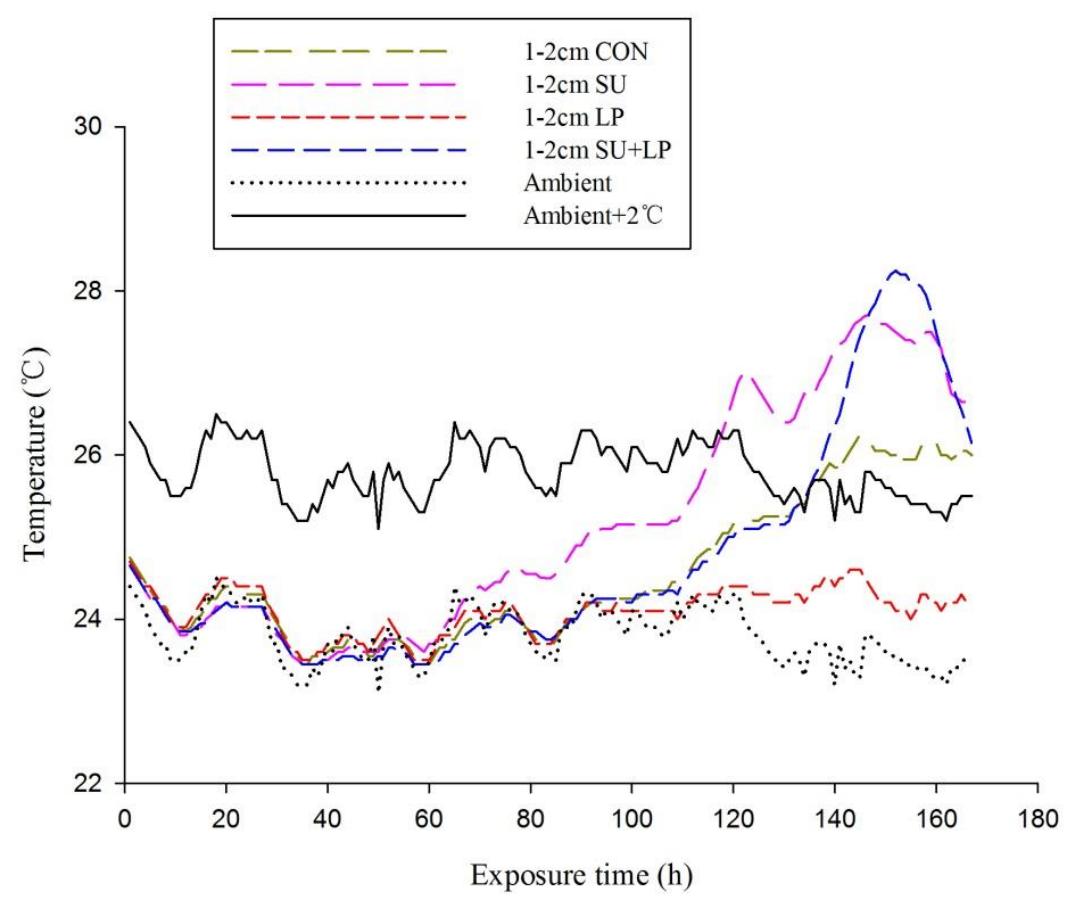

Figure 1. The temperature changes of $L$. chinensis silage at a length of $1-2 \mathrm{~cm}$ with the time of aerobic. exposure. CON, control; SU, sucrose; LP, Lactobacillus plantarum.

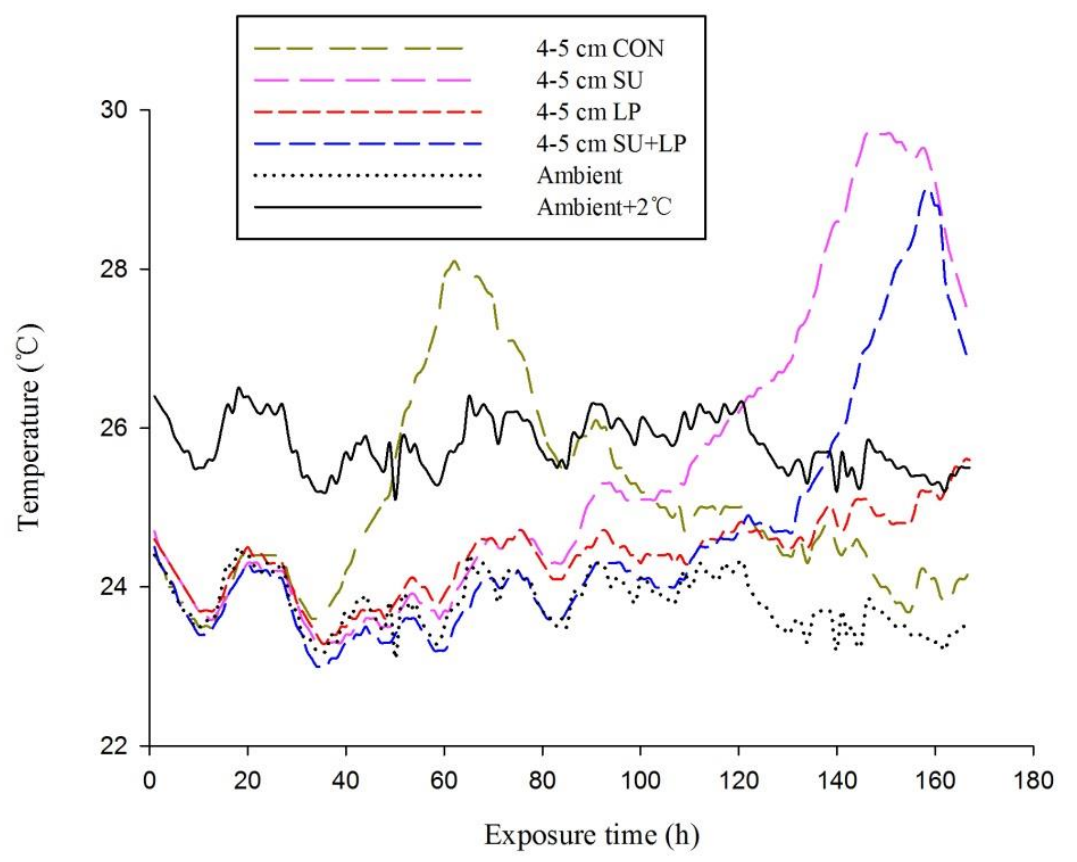

Figure 2. The temperature changes of L. chinensis silage at a length of $4-5 \mathrm{~cm}$ with the time of aerobic exposure. CON, control; SU, sucrose; LP, Lactobacillus plantarum. 
Table 4. Significant analyzes of length, additive, and their interactions on aerobic stability, maximum temperature and the time to maximum temperature of L. chinensis silage.

\begin{tabular}{ccccc}
\hline \multicolumn{2}{c}{ Treatments } & $\begin{array}{c}\text { Aerobic Stability } \\
\text { (h) }\end{array}$ & $\begin{array}{c}\text { Maximum Temperature } \\
\left({ }^{\circ} \mathbf{C}\right)\end{array}$ & $\begin{array}{c}\text { Time to Maximum } \\
\text { Temperature (h) }\end{array}$ \\
\hline \multirow{2}{*}{ Length } & $<0.001$ & 0.088 & $<0.001$ \\
\hline & Additive & $<0.001$ & 0.010 & $<0.001$ \\
\hline
\end{tabular}

\subsection{Changes of $\mathrm{pH}$ Value and Acidic Substances of L. chinensis Silage}

The dynamic changes in the $\mathrm{pH}$ value and LA content during the process of aerobic exposure of $L$. chinensis silage with different chopping lengths and different additives are given in Figure 3. At $1-2 \mathrm{~cm}$, with no additives, the $\mathrm{pH}$ value remained stable after the silo had been opened for $3 \mathrm{~d}$, and it increased $5 \mathrm{~d}$ after exposure to air. With the addition of LP, the $\mathrm{pH}$ value did not change after the silo had been opened for $5 \mathrm{~d}$, but it increased $7 \mathrm{~d}$ after exposure to air (Figure 3A); after exposure to air for $3 \mathrm{~d}$, the LA content of the control silage with no additives and the LP- and SU+LP-treated silage remained stable. With the addition of SU, the LA content decreased from $27.42 \mathrm{~g} / \mathrm{kg} \mathrm{DM}$ to $17.12 \mathrm{~g} / \mathrm{kg}$ DM. Additionally, the LA content was close to 0 during the $7-d$ spoilage test for all treatments (Figure 3B). At $4-5 \mathrm{~cm}$, with the addition of LP or SU+LP, the $\mathrm{pH}$ value was lower compared to the control and remained stable after the silo had been opened for $5 \mathrm{~d}$ and increased $7 \mathrm{~d}$ after exposure to air. With the addition of SU or with no additives, the $\mathrm{pH}$ value tended to increase after $3 \mathrm{~d}$ of exposure to air (Figure 3C); the LA content of L. chinensis silage treated with LP or SU+LP was higher than that of the control or silage treated with $\mathrm{SU}$ on 0 to $5 \mathrm{~d}$ of aerobic exposure. After aerobic exposure for $7 \mathrm{~d}$, the LA content was close to 0 for all treatments (Figure 3D).
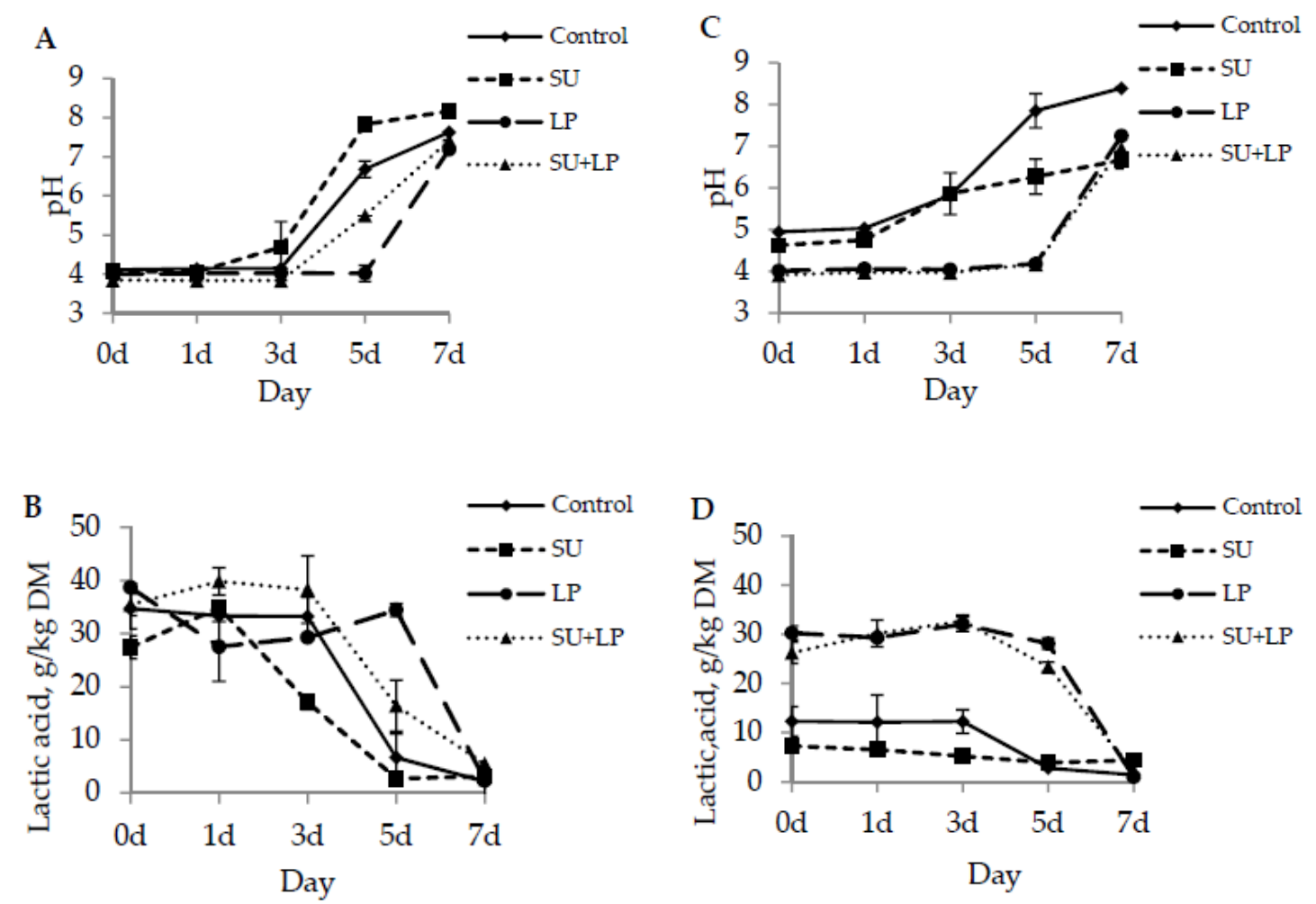

Figure 3. Dynamic changes in the $\mathrm{pH}$ value during aerobic exposure of L. chinensis silage treated with different additives at 1-2 cm length (A) and 4-5 cm length (C). Dynamic changes in the lactic acid content during aerobic exposure of L. chinensis silage with different additives at 1-2 cm length (B) and 4-5 cm length (D). SU, sucrose; LP, Lactobacillus plantarum; DM, dry matter. 
The dynamic changes in the acetic acid, propionic acid and butyric acid contents during aerobic exposure of L. chinensis silage with different chopping lengths and different additives are given in Figure 4. At 1-2 cm, the AA content decreased after silo opening during the 7-d spoilage test. After $7 \mathrm{~d}$ of aerobic exposure, the AA content of L. chinensis silage treated with LP was $11.72 \mathrm{~g} / \mathrm{kg}$ DM, which in the other treatments was close to 0 (Figure $4 \mathrm{~A}$ ); the PA content fluctuated from $5 \mathrm{~g} / \mathrm{kg}$ DM to $15 \mathrm{~g} / \mathrm{kg}$ $\mathrm{DM}$ and decreased after $7 \mathrm{~d}$ of aerobic exposure (Figure 4B); after exposure to air for $3 \mathrm{~d}$, BA was detected on all the days with the addition of SU. In contrast, BA was not detected at any number of days of aerobic exposure with the addition of LP (Figure 4C). At $4-5 \mathrm{~cm}$, the AA content of L. chinensis silage treated with LP and SU+LP was higher than that of control and SU at 0 to $7 \mathrm{~d}$ after aerobic exposure. After aerobic exposure for $7 \mathrm{~d}$, the AA content was close to 0 for all treatments (Figure 4D); no regular changes of the PA content were detected after the silo had been opened for $7 \mathrm{~d}$ (Figure $4 \mathrm{E}$ ); BA was detected at $7 \mathrm{~d}$ of aerobic exposure in the SU and control, but was not detected in LP and $\mathrm{SU}+\mathrm{LP}$ treatments at 0 to $5 \mathrm{~d}$ of aerobic exposure (Figure $4 \mathrm{~F}$ ).
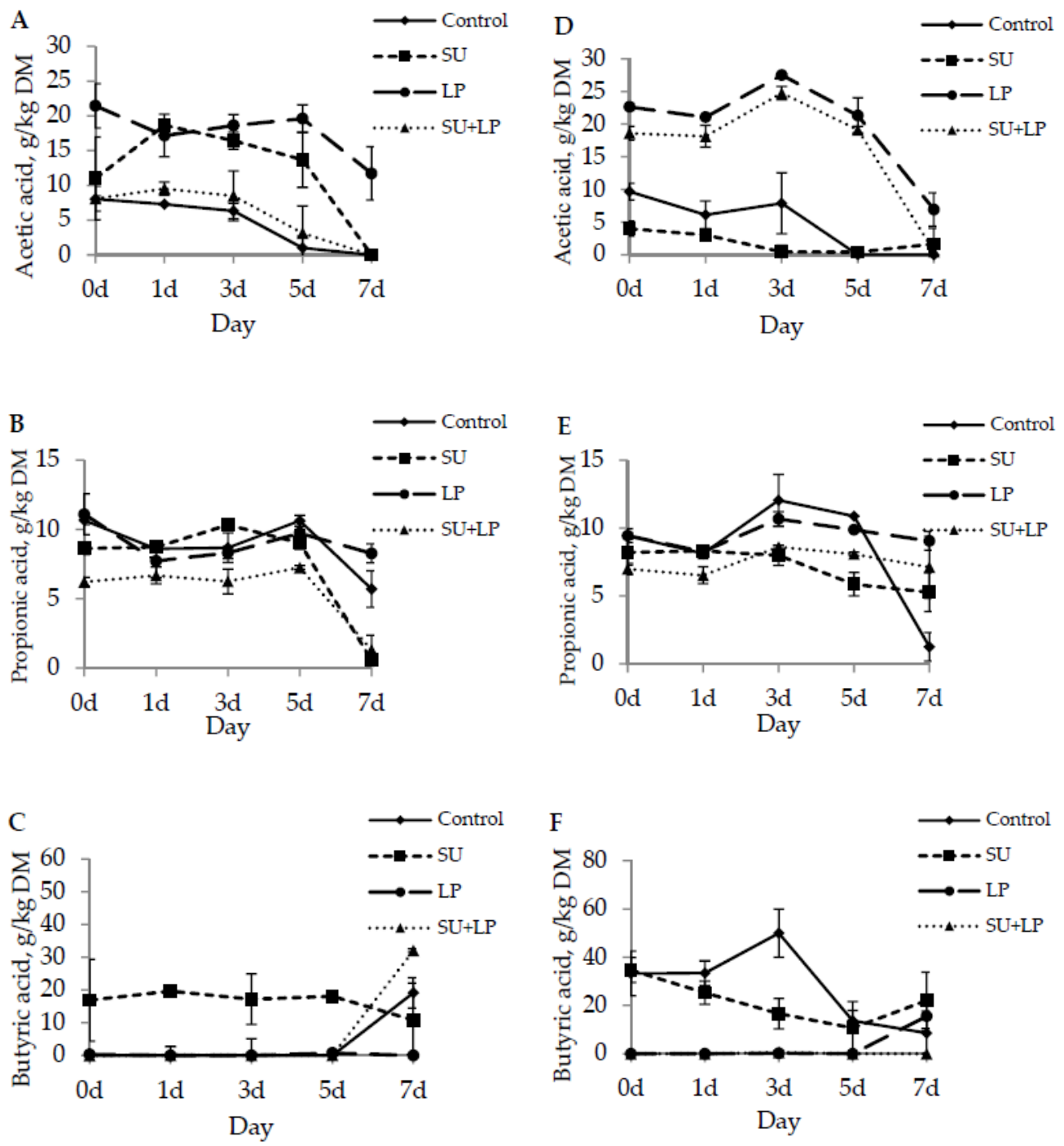

Figure 4. Dynamic changes in the acetic acid content during aerobic exposure of L. chinensis silage with different additives at 1-2 cm length (A) and 4-5 cm length (D). Dynamic changes in the propionic acid content during aerobic exposure of L. chinensis silage with different additives at 1-2 cm length (B) and 4-5 cm length (E). The dynamic changes in the butyric acid content during aerobic exposure of $L$. chinensis silage with different additives at 1-2 cm length (C) and 4-5 cm length (F). SU, sucrose; LP, Lactobacillus plantarum; DM, dry matter. 


\section{Discussion}

The contents of WSC and LAB are critical for successful ensilage. Previous studies showed that with a low WSC content, inoculants will not produce enough LA due to the limitations of the substrates, and the presence of sufficient LAB can convert WSCs into LA and lower the $\mathrm{pH}$ value in an anaerobic environment $[24,25]$. However, previous research also showed that relatively low contents of WSC and LAB were observed in L. chinensis $[10,26]$. Therefore, in order to promote fermentation, it is necessary to supplement WSC or LAB inoculants. In addition, the L. chinensis stalk is hollow and hard; thus, removing all the air when making silage is difficult [10]. Compacting and chopping were used to exhaust the air from L. chinensis stems to make high-quality L. chinensis silage. In our experiments, SU, $\mathrm{LP}$ and SU+LP were added to L. chinensis silage, which was cut into different lengths. The $\mathrm{pH}$ value is an important factor that reflects the silage quality, and a $\mathrm{pH}$ value below 4.20 is considered an important key indicator for inhibiting the growth of contaminating microorganisms [27]. For processing silage, the key factors that determine the $\mathrm{pH}$ value are the LA and AA contents. Lower $\mathrm{pH}$ value and higher LA content were obtained in L. chinensis silage with the shorter chopping length, which was consistent with the results of Savoie et al. [12]. Additionally, lower $\mathrm{pH}$ value and higher LA content were detected with the SU+LP treatment at all lengths. Moreover, the results of ensiling for $30 \mathrm{~d}$ and $90 \mathrm{~d}$ were similar. Usually, both biological (mainly consisting of homofermentative LAB) and chemical additives are used to improve silage quality $[28,29]$. The addition of homofermentative LAB to forage at ensiling can enhance the fermentation process by producing high concentrations of LA and rapidly reducing the $\mathrm{pH}$ of the silage [17]. Similar results were found in our experiments. In addition, we found that when the cut length was $4-5 \mathrm{~cm}$, all additives showed positive effects on L. chinensis preservation, and $\mathrm{LP}$ or SU+LP treatments resulted in lower $\mathrm{pH}$ values and higher LA contents. Lactobacillus buchneri (LB) were reported to increase the AA content, and L. plantarum (i.e., LP in this study) was shown to increase the LA content $[23,30]$. In our study, inoculation of the L. chinensis silage with LP increased the AA content and thereby affected the lactate:acetate ratio, which might be related to the lack of effect of inoculation on certain fermentation end products. However, the increased BA content upon the addition of SU with ensiling for $90 \mathrm{~d}$ was difficult to explain, and it may have arisen from Clostridia reproduction in the silage [31]. The yeast count of the $4-5 \mathrm{~cm}$ length with no additives was $1 \times 10^{3.63}$ $\mathrm{cfu} / \mathrm{g}$ FM, which was higher than the count in the other treatments. The results showed that the yeast number was inhibited by the length of chopping and additives.

The aerobic deterioration of silage is a significant problem for farm profitability and feed quality throughout the world [32,33]. After the silo was opened, the anaerobic environment became aerobic immediately, and aerobic microorganisms began to reproduce. Generally, the aerobic deterioration of silage is mainly caused by the activities of aerobic microorganisms such as yeast and mold, which use the LA and residual carbohydrates, amino acids and proteins produced by silage fermentation to release heat from the silage and cause the deterioration of aerobic metamorphism [34]. In this study, when the cutting length was $4-5 \mathrm{~cm}$, the yeast and mold levels of L. chinensis silage were higher than those in all the other treatments, and the aerobic stability of L. chinensis silage was poorest with no additives. Molasses and LAB have been reported to promote resistance to aerobic deterioration [35,36], and similar results were found in this study. When the chopping length was longer, the aerobic stability increased with the addition of SU, LP and SU+LP. In addition, we found that L. chinensis silage is resistant to aerobic deterioration for 5-7 d in all treatments at the 1-2 cm chopping length. Zhang et al. [10] investigated the aerobic stability of L. chinensis silage at $54.8 \mathrm{~h}$ and found that the stability was lower than that observed in our study. This finding may be due to the different moisture contents of the materials. In our experiment, the DM of the L. chinensis material was $450.06 \mathrm{~g} / \mathrm{kg}$, which was higher than $327.3 \mathrm{~g} / \mathrm{kg}$ that observed in previous study [10].

In our study, we found that when the chopping length was shorter, the $\mathrm{pH}$ value of L. chinensis silage in all treatments remained stable after exposure to air for $3 \mathrm{~d}$. The addition of LP increased the AA content only after silo opening. Combined with the influence of the aerobic temperature, the effect of additives on the aerobic stability of L. chinensis silage with a shorter length was not apparent. 
Many microorganisms are able to aerobically metabolize sugars and LA. The content of LA has been reported to decrease with exposure time [10]. Similar results were observed in our study, and the LA content was close to 0 on the 7th day of aerobic exposure for all treatments. In addition, we found that BA could be detected with the addition of SU. This finding may be related to the use of sugar by Clostridium undergoing nutritional reproduction [35]. Considering the high BA content in silage treated with SU alone, SU+LP could be used to inhibit the aerobic deterioration of L. chinensis silage. When the chopping length was $4-5 \mathrm{~cm}$, the addition of LP or SU+LP greatly increased the LA content of $L$. chinensis silage during anaerobic fermentation and enhanced AA production. Previous studies found that an increase in the AA content could improve aerobic stability [30]. In our study, when the chopping length was $4-5 \mathrm{~cm}$, the addition of LP or SU+LP led to stable $\mathrm{pH}$ values after the silo was opened for $5 \mathrm{~d}$, and the aerobic stabilities were $157 \mathrm{~h}$ and $143 \mathrm{~h}$, respectively. Therefore, the enhanced aerobic stability observed in the silage treated with LP or SU+LP can be partly attributed to the increased AA content after the silos were opened [5]. In addition, at the $4-5 \mathrm{~cm}$ length, the content of BA was not detected in LP and SU+LP treatments at 0 to $5 \mathrm{~d}$ of aerobic exposure, which exhibited low $\mathrm{pH}$ values. This might be explained by the growth of microorganisms, such as yeast and coliform bacteria, which were inhibited at low $\mathrm{pH}$ values [14,37]. However, the microbial community was not measured in our study, which represents a limitation of the presented work. In the future, the microbial community of L. chinensis silage could be explored to determine the changes of acidic substances during ensiling and aerobic exposure.

\section{Conclusions}

The chopping length affected the fermentation quality on processing of L. chinensis silage, and the longer length resulted in negative effects. The lower $\mathrm{pH}$ value, higher LA content and better aerobic stability were obtained at 1-2 cm length. The additives of LP or SU+LP could be used to improve the fermentation quality and aerobic stability during processing of L chinensis silage.

In summary, to ensure the high quality of L. chinensis silage, the recommended length of L. chinensis is $1-2 \mathrm{~cm}$; otherwise, appropriate additives should be provided to improve the fermentation quality and aerobic stability.

Author Contributions: Z.Y. and T.J. designed the study. Z.S. and R.G. analyzed the data. Z.S. and T.J. wrote the manuscript. S.X., Z.W., and B.W. revised the manuscript. All authors have read and agreed to the published version of the manuscript.

Funding: The work was financially supported by the China Forage and Grass Research System (CARS-34), the Key Technologies Research and Demonstration for Efficient Utilization of Modern Artificial Grassland (2017BY082), and the Demonstration Project of Exploitation and Utilization of High Quality Green and Rough Feed Resources (16190051).

Acknowledgments: We thank Shangang Jia in College of Grassland Science and Technology in China Agricultural University, for his help in the revision of manuscript.

Conflicts of Interest: The authors declare no conflict of interest.

\section{References}

1. Zhang, Q.; Yu, Z.; Na, R.S. Effects of different additives on fermentation quality and aerobic stability of Leymus chinensis silage. Grass Forage Sci. 2018, 73, 413-419. [CrossRef]

2. Peng, X.; Zhang, L.; Zhang, L.; Liu, Z.; Cheng, L.; Yang, Y.; Shen, S.; Chen, S.; Liu, G. The transcriptional factor LcDREB2 cooperates with LcSAMDC2 to contribute to salt tolerance in Leymus chinensis. Plant Cell Tiss. Org. 2013, 113, 245-256. [CrossRef]

3. Chen, S.; Huang, X.; Yan, X.; Liang, Y.; Wang, Y.; Li, X.; Peng, X.; Ma, X.; Zhang, L.; Cai, Y. Transcriptome analysis in sheepgrass (Leymus chinensis): A dominant perennial grass of the Eurasian steppe. PLoS ONE 2013, 8, e67974. [CrossRef] [PubMed] 
4. Niu, W.; He, Y.; Wang, H.; Xia, C.; Shi, H.; Cao, B.; Su, H. Effects of Leymus chinensis replacement with whole-crop wheat hay on blood parameters, fatty acid composition, and microbiomes of Holstein bulls. J. Dairy Sci. 2018, 101, 246-256. [CrossRef]

5. Zhang, Q.; Li, X.J.; Zhao, M.M.; Yu, Z. Isolating and evaluating LAB strains for effectiveness of Leymus chinensis silage fermentation. Lett. Appl. Microbiol. 2014, 59, 391-397. [CrossRef]

6. Bondarev, V.A.; Pobednov, Y.A. Improving technologies for fodder production and storage. Kormoproizvodstvo 2001, 3, 27-32.

7. McDonald, P.; Henderson, A.R.; Heron, S.J.E. The Biochemistry of Silage; Chalcombe Publications: Marlow, UK, 1991; 340p.

8. Coblentz, W.K.; Akins, M.S. Silage review: Recent advances and future technologies for baled silages. J. Dairy Sci. 2018, 101, 4075-4092. [CrossRef]

9. Tian, J.; Yu, Y.; Zhu, Y.; Tao, S.; Zhao, M. Effects of LAB inoculants and cellulase on fermentation quality and in vitro digestibility of Leymus chinensis silage. Grassl. Sci. 2014, 60, 199-205. [CrossRef]

10. Zhang, Q.; Li, X.; Zhao, M.; Yu, Z. Lactic acid bacteria strains for enhancing the fermentation quality and aerobic stability of Leymus chinensis silage. Grass Forage Sci. 2016, 71, 472-481. [CrossRef]

11. Zhang, Q.; Yu, Z. Characterization, identification and application of LAB isolated from Leymus chinensis silage. Grassl. Sci. 2017, 63, 111-117. [CrossRef]

12. Savoie, P.; Tremblay, D.; Tremblay, G.F.; Wauthy, J.M.; Flipot, P.M.; Theriault, R. Effect of length of cut on quality of stack silage and milk-production. Can. J. Anim. Sci. 1992, 72, 253-263. [CrossRef]

13. Huisden, C.M.; Adesogan, A.T.; Kim, S.C.; Ososanya, T. Effect of applying molasses or inoculants containing homofermentative or heterofermentative bacteria at two rates on the fermentation and aerobic stability of corn silage. J. Dairy Sci. 2009, 92, 690-697. [CrossRef] [PubMed]

14. Heinritz, S.N.; Martens, S.D.; Avila, P.; Hoedtke, S. The effect of inoculant and sucrose addition on the silage quality of tropical forage legumes with varying ensilability. Anim. Feed Sci. Technol. 2012, 174, 201-210. [CrossRef]

15. Wu, B.; Nishino, N. Identification and isolation of Lactobacillus fructivorans from wilted alfalfa silage with and without molasses. J. Appl. Microbiol. 2016, 120, 543-551. [CrossRef] [PubMed]

16. McEniry, J.; King, C.; O'Kiely, P. Silage fermentation characteristics of three common grassland species in response to advancing stage of maturity and additive application. Grass Forage Sci. 2014, 69, 393-404. [CrossRef]

17. Thomson, A.L.; Humphries, D.J.; Kliem, K.E.; Dittmann, M.T.; Reynolds, C.K. Effects of replacing maize silage with lucerne silage and lucerne silage chop length on rumen function and milk fatty acid composition. J. Dairy Sci. 2017, 100, 7127-7138. [CrossRef] [PubMed]

18. Xu, Q.F.; Yu, Z.; Han, J.G. HPLC method for organic acid of alfalfa silages. Grassl. Turf. 2007, 2, 63-67. [CrossRef]

19. Zhang, Q.; Yu, Z.; Yang, H.; Na, R.S. The effects of stage of growth and additives with or without cellulase on fermentation and invitro degradation characteristics of Leymus chinensis silage. Grass Forage Sci. 2016, 71, 595-606. [CrossRef]

20. Vansoest, P.J.; Robertson, J.B.; Lewis, B.A. Methods for dietary fiber, neutral detergent fiber, and nonstarch polysaccharides in relation to animal nutrition. J. Dairy Sci. 1991, 74, 3583-3597. [CrossRef]

21. AOAC. Official Methods of Analysis of the Association of Official Analytical Chemists, 15th ed.; The Association: Arlington, VA, USA, 1990.

22. McDonald, P.; Henderson, A.R. Determination of water-soluble carbohydrates in grass. J. Sci. Food Agric. 1964, 15, 395-398. [CrossRef]

23. Ranjit, N.K.; Kung, L. The effect of Lactobacillus buchneri, Lactobacillus plantarum, or a chemical preservative on the fermentation and aerobic stability of corn silage. J. Dairy Sci. 2000, 83, 526-535. [CrossRef]

24. Seale, D.R.; Henderson, A.R.; Pettersson, K.O.; Lowe, J.F. The effect of addition of sugar and inoculation with 2 commercial inoculants on the fermentation of lucerne silage in laboratory silos. Grass Forage Sci. 1986, 41, 61-70. [CrossRef]

25. Nadeau, E.M.G.; Buxton, D.R.; Russell, J.R.; Allison, M.J.; Young, J.W. Enzyme, bacterial inoculant, and formic acid effects on silage composition of orchardgrass and alfalfa. J. Dairy Sci. 2000, 83, 1487-1502. [CrossRef] 
26. Xue, Y.; Bai, C.; Sun, J.; Sun, L.; Chang, S.; Sun, Q.; Yu, Z.; Yin, G.; Zhao, H.; Ding, H. Effects of locations and growth stages on nutritive value and silage fermentation quality of Leymus chinensis in Eurasian steppe of northern China. Grassl. Sci. 2018, 64, 40-50. [CrossRef]

27. Randby, A.T.; Gismervik, K.; Andersen, A.; Skaar, I. Effect of invasive slug populations (Anon vulgaris) on grass silage I. Fermentation quality, in-silo losses and aerobic stability. Anim. Feed Sci. Technol. 2015, 199, 10-19. [CrossRef]

28. Muck, R.E.; Nadeau, E.M.G.; McAllister, T.A.; Contreras-Govea, F.E.; Santos, M.C.; Kung, L., Jr. Silage review: Recent advances and future uses of silage additives. J. Dairy Sci. 2018, 101, 3980-4000. [CrossRef]

29. Queiroz, O.C.M.; Arriola, K.G.; Daniel, J.L.P.; Adesogan, A.T. Effects of 8 chemical and bacterial additives on the quality of corn silage. J. Dairy Sci. 2013, 96, 5836-5843. [CrossRef]

30. Danner, H.; Holzer, M.; Mayrhuber, E.; Braun, R. Acetic acid increases stability of silage under aerobic conditions. Appl. Environ. Microbiol. 2003, 69, 562-567. [CrossRef]

31. Spoelstra, S.F. Comparison of the content of Costridial spores in wilted grass-silage ensiled in either laboratory, pilot-scale or farm silos. Neth. J. Agr. Sci. 1990, 38, 423-434. [CrossRef]

32. Tabacco, E.; Righi, F.; Quarantelli, A.; Borreani, G. Dry matter and nutritional losses during aerobic deterioration of corn and sorghum silages as influenced by different LAB inocula. J. Dairy Sci. 2011, 94, 1409-1419. [CrossRef]

33. Wilkinson, J.M.; Davies, D.R. The aerobic stability of silage: Key findings and recent developments. Grass Forage Sci. 2013, 68, 1-19. [CrossRef]

34. Hu, W.; Schmidt, R.J.; McDonell, E.E.; Klingerman, C.M.; Kung, L., Jr. The effect of Lactobacillus buchneri 40788 or Lactobacillus plantarum MTD-1 on the fermentation and aerobic stability of corn silages ensiled at two dry matter contents. J. Dairy Sci. 2009, 92, 3907-3914. [CrossRef] [PubMed]

35. Jonsson, A. Growth of clostridium-tyrobutyricum during fermentation and aerobic deterioration of grass-silage. J. Sci. Food Agric. 1991, 54, 557-568. [CrossRef]

36. Ferrero, F.; Piano, S.; Tabacco, E.; Borreani, G. Effects of conservation period and Lactobacillus hilgardii inoculum on the fermentation profile and aerobic stability of whole corn and sorghum silages. J. Sci. Food Agric. 2019, 99, 2530-2540. [CrossRef]

37. Arriola, K.G.; Kim, S.C.; Adesogan, A.T. Effect of applying inoculants with heterolactic or homolactic and heterolactic bacteria on the fermentation and quality of corn silage. J. Dairy Sci. 2011, 94, 1511-1516. [CrossRef]

Publisher's Note: MDPI stays neutral with regard to jurisdictional claims in published maps and institutional affiliations.

(C) 2020 by the authors. Licensee MDPI, Basel, Switzerland. This article is an open access article distributed under the terms and conditions of the Creative Commons Attribution (CC BY) license (http://creativecommons.org/licenses/by/4.0/). 